\title{
"Navigating the Different Spaces": Experiences of Inclusion and Isolation Among Racially Minoritized Faculty in Canada
}

\author{
Marlee M. Spafford \\ School of Optometry, University of Waterloo \\ Vicki L. Nygaard \\ Intercultural Education and Training Program, University of Victoria \\ Fran Gregor \\ School of Nursing, Dalhousie University \\ Marcia A. Boyd \\ Faculty of Dentistry, University of British Columbia (Professor Emerita)
}

\begin{abstract}
The intersection of multiple identities (e.g., racialization, gender, class) strongly determines an individual's social location. In-depth interviews with 42 racially minoritized academics in Canadian universities allowed U.S. to begin to grasp the challenges faced by those who must negotiate the different spaces in an academy that is predominately white, Eurocentric and male. Using an anti-racist framework, we found that the level of inclusion that racially minoritized academics in our study felt within their workplaces depended upon their experiences with 1) acceptance (e.g., through hiring, promotion, and tenure); 2) visibility (e.g., in terms of perceived power in informal and formal work interactions); 3) support (e.g., via collegial and administrative encouragement, assistance, collaboration and resource support); and 4) mentoring (e.g., in terms of providing and seeking mentor experiences). Our findings suggest that the increasing presence of
\end{abstract}


racially minoritized academics may better serve institutional purposes of portraying a mission of diversity than actually achieving a mission of equity.

\section{RÉSUMÉ}

Le croisement des identités multiples telles que la racialisation, le genre et la classe sociale détermine fortement la position sociale de l'individu. Quarante-deux professeurs universitaires canadiens membres de minorités visibles se sont prêtés à une entrevue approfondie afın de mieux comprendre les obstacles et défis qu'ils doivent surmonter dans un milieu majoritairement dominé par des hommes blancs d'origine européenne. Analysées dans une perspective anti-raciste, ces entrevues indiquent que le niveau d'intégration au milieu académique perçu par ces professeurs issus de groupes minorisés est associé à certains critères tels que: 1) l'acceptation (comme l'embauche, l'avancement, la titularisation), 2) la visibilité (comme l'influence dans les relations de travail formelles et informelles), 3) le soutien (offert par les collègues ou l'administration par exemple) et 4) le mentorat (comme l'accès aux conseils d'un collègue plus expérimenté). L'analyse des résultats démontre que la présence accrue de professeurs issus de groupes minorisés sert surtout à afficher que l'institution se diversifie plutôt que de réellement améliorer l'équité entre les différents groupes sociaux.

\section{INTRODUCTION}

Interviewer: Do you think that as a woman, you do any of the work that you do - in your teaching or research - differently than comparable men do?

Academic: I don't know how to answer that question because I'm saying to myself, "I'm not just a woman, I'm a visible minority woman." So it is that combination that ... makes a big difference. I am the only non-White woman in the faculty.

The above excerpt from our study of Canadian faculty ${ }^{1}$ points to the complexities created by the intersection of difference in an academy that is predominately White, Eurocentric and male. This academic (A16) ${ }^{2}$ was faced with the challenges of (in the words of participant A25) "navigating the different spaces" she occupied as a woman of colour in a White man's world. Our work is informed by an understanding that the intersection of multiple identities (e.g., ethnicity, gender, class, sexual orientation, ability, age, size) strongly determines the individual's social location (Alcoff, 1988; Dei, 1996; Maher \& Tetreault, 1993). We contend that identities are not constructed individually and cannot be understood as separate entities, as liberal feminists assume about gender and racialization. The danger of liberal feminism is that the participant's 
experiences are seen through the normative lens of the White, middle-class experience (Alcoff, 1988; Dei, 1996; Maher \& Tetreault, 1993). While genderonly analyses offer evidence that women are disadvantaged in the academy (e.g., Benoit, 2000; Reynolds, 2001; Wennerås \& Wold, 1997), the increasing impact of additional identities must be examined to better understand the complexity of marginalization.

In our study of the Canadian academy, we focused on eight academic disciplines (dentistry, education, law, nursing, optometry, pharmacy, social work, and sociology) that have been historically "White"3 and, with the exception of nursing and social work, male (Evans, 2004, McLean, 2003). Racially minoritized ${ }^{4}$ students and academics have reported experiences of disconnection and isolation in the American higher education system (Blackwell, 1989; Boice, 1993; Reid \& Wilson, 1993). These experiences of inclusion or lack thereof for racially minoritized academics needs to be assessed across the Canadian landscape as there are indications that non-White Canadians too are treated differently than their White counterparts (Dhruvarajan, 1996; Hannah et al., 2002; Mukherjee, 2001; Ng, 1994; Rajagopal, 2002).

Our goal in this paper is to identify and understand some of the challenges faced by racially minoritized academics in Canadian universities. We approach this goal using the interpretive lens of an anti-racist framework in an attempt to inspire dialogue that may lead to real changes in equity within Canadian academic institutions.

\section{Conceptual Framework}

Anti-racist critical theory argues that (1) racialization has and continues to be a fundamental organizing principle of society; (2) racism is "normal" in that it is "the usual way society does business, the common, everyday experience of most people of color" (Delgado \& Stefancic, 2001, p. 7); (3) racially minoritized people have a unique voice because of their social position and experiences of oppression; and (4) social justice is a central goal of anti-racist frameworks (Calliste, 2000; Dei, 1996; Dua \& Robertson, 1999; Luther et al., 2003; McDowell \& Jeris, 2004). Anti-racist critical theorists view "race" as a social construct that legitimates various asymmetries of power. They interrogate and challenge practices, both public and private, that hinge on racist epistemologies (e.g., Calliste, 2000; Collins, 1998; Dei, 1996). We argue that the academy, where the everyday business is the construction and dissemination of knowledge, is an important place to examine epistemologies that can and do constrain its users and their future.

\section{Negotiating the Different Spaces in Academia}

The intersection of racialization and gender affects hiring patterns in higher education. Rajagopal (2002) found that, in Canada, women and racial minorities represent a higher proportion of hires among non-tenured than among tenure- 
track faculty. In the mid-1990s, faculty of colour accounted for only 10\% of the American professoriate and these appointments were concentrated in two-year colleges and non-tenure track positions (Astin et al., 1997). These patterns of inequity are reported widely (CAUT, 2004; Levinson \& Weiner, 1991; Menges \& Exum, 1983; Palepu et al., 1998; Petersdorf et al., 1989; Turner, et al., 1999; Wild, 2000; Wilson, 1987) and they echo the racial exclusivity of elite professions (Sokoloff, 1992; Staples, 1984). Contingent academic workers (i.e., full-time non-tenured, part-time non-tenured, sessional, contractual, and part-time adjunct), comprise between one-third and two-thirds of the North American academic workforce (CAUT, 2004; Moser, 2000; Mullens, 2001; Mysyk, 2001; Tudiver, 1999). ${ }^{5}$ These "invisible faculty" (Gappa \& Leslie, 1993) face heavy workloads, reduced salaries, limited visibility and restricted benefits (Muzzin, 2003; Nygaard, 2002). With racially minoritized faculty making up a large sector of the academic contingent workforce, the plight of contingent workers is particularly relevant to racially minoritized academics.

Studies of academics suggest that women and racially minoritized individuals are judged more harshly than their White male counterparts. The largest body of literature examining North American racially minoritized academics pertains to Black men and women. Their experiences reflect similar themes in studies of other racially minoritized academics (e.g., Graveline, 2000), although some have suggested that the experiences of Blacks represent some of the most dramatic examples of academic racism in North America (Lewis, 1992; Palepu, et al., 1998; Turner et al., 1999). With a professorial representation of only $0.7 \%$, "Aboriginal Canadians are largely absent from the ranks of academia" (CAUT, 2004, p. 1); this finding is suggestive of systemic racism. The relatively larger representation of Asian academics, particularly in science and engineering, has supported misconceptions that Asian faculty enjoy "exemplary" experiences (Turner et al., 1999; p. 28) devoid of racial or ethnic bias (Nakanishi, 1993). Yet, Asian academics have reported negative experiences due to stereotyping that undermine their career satisfaction (Astin, 1982; Mukherjee, 2001; Nakanishi, 1993; Turner et al., 1999).

Overall, the literature provides a negative portrait of the work lives of racially minoritized academics. They are vastly under-represented among those with PhDs (Chandler, 1996; Sokoloff, 1992) and those with full-time faculty appointments in higher education (Allen et al., 2000; Darden et al., 1998; Flowers \& Jones, 2003; Staples, 1984). They encounter inequitable hiring and promotion practices (Calhoun, et al., 1990; Leap, 1995; Staples, 1984; Wilson, 1997), which Staples (1984) argues are typical of the non-standardized, arbitrary recruitment and evaluation processes employed in the White-collar-world. Wilson (1997) adds that hiring and promotion practices are not necessarily "discriminatory in intent, but [they] serve to disproportionately exclude racial minorities" (p. 39). Racially minoritized faculty historically have achieved notably lower retention rates compared with their White counterparts due, in part, to lower rates of tenure (Scott, 1981; Staples, 1984). In addition, administrators and search committees 
have been unwilling to provide or are unaware of the necessary resources to recruit and retain racially minoritized faculty (Knowles \& Harleston, 1997).

Staples (1984) argues that racially minoritized faculty face widespread intellectual racism (see James \& Shadd [2001] for more on intellectual racism). They are apt to be labeled pedagogically "biased" because teaching courses with a focus on "racialization" is seen as protecting "their own" while teaching courses other than those is considered outside "their field." Racially minoritized academics are often assumed by Whites to be interested in or able to study only their own racialized group and, despite prolific output, racially minoritized academics may face a "not good enough" meritocracy discourse when it comes to tenure and promotion decisions. The research interests of racially minoritized faculty are more likely to be devalued either because the research area is not considered "traditional" or because there are low race-related expectations of the faculty member's performance (Battiste et al., 2002; Battiste, 1998; Garza, 1993; Marker, 1998; Nakanishi, 1993; Paterson \& Hart-Wasekeesikaw, 1994; Sands et al., 1992; Steinhauer, 1998). The literature also suggests that the heaviest teaching and service loads tend to fall on women and racially minoritized faculty with the latter being pressured to accept heavy service assignments with a "minority focus" geared toward show-casing diversity on campus (Krouse, 1999).

Although studies of women (Dreher \& Ash, 1990; Riley \& Wrench, 1985) and racially minoritized women (Morgan, 1993; Ramey, 1993) reveal greater job success and satisfaction in the presence of mentors, these cohorts are unlikely to experience mentorship and support in academia (Essien, 2003; Turner et al., 1999). Racially minoritized faculty members are also more likely than Whites to find themselves excluded from their department's informal networks which can provide opportunities for connections and mentorship with senior colleagues (Essien, 2003). This isolation creates challenges for racially minoritized faculty who must negotiate the socialization process alone (Boice, 1993).

In summary, racially minoritized faculty face barriers that in turn decrease their visibility, voice and "incorporation" within the formal and informal power relations of the academy (Essien, 2003; Turner, 2003). Turner (2003) cautions that equity within the academy will not improve if incorporation is merely a disguise for assimilation. Racially minoritized faculty must be able to be seen and be valued through something other than the normative lens of the White middle-class.

\section{Purpose}

As we conducted our research, we used an anti-racist critical perspective to examine the experiences of racially minoritized faculty for indications of problematic power relations within the Canadian academy. We believed that a logical, albeit undesirable, sequela of systemic power asymmetries within the academy would be a lack of inclusion experienced by those with less power. In order to address this issue, we looked for reasonable indicators of 
an academic's sense of "inclusion" or lack thereof. Through this process, we identified four types of experiences that we felt were relevant to one's sense of inclusion: acceptance (i.e., hiring, promotion, and tenure experiences), mentoring (i.e., providing and seeking mentor experiences), support (i.e., collegial and administrative encouragement, collaboration and resource support experiences), and/or visibility (i.e., perceived power in informal and formal work interaction experiences). In their negative form, these experiences echo the elements of what has been described as the "chilly climate" that women faculty face (The Chilly Collective, 1995; Stalker \& Prentice, 1998) although care must be taken to further address the impact that multiple identities has on this climate (Benjamin, 1997; Dhruvarajan, 1996; Mukherjee, 2001; Ng, 1994). Thus, our overall research question was, "Do the work experiences of racially minoritized faculty provide them with a sense of being 'included' or 'excluded' in the Canadian academy?" And towards addressing this broader question, we asked, "What are the experiences of racially minoritized faculty in Canada regarding acceptance, mentoring, support, and/or visibility?"

Herein, we focus on 42 interviews of racially minoritized faculty, who negotiate and challenge these different spaces on a daily basis in Canadian universities.

\section{POSITIONING OURSELVES}

We have been part of a SSHRC-funded research group studying the working lives of academics in Canada. Our work has highlighted for U.S. the impact that intersecting multiple identities has on academics. While acknowledging our social location as racially privileged White women, we seek to increase our awareness of racialization and commitment to anti-racist activity. This type of approach is supported by D'Andrea and Daniels (1999) who describe a principled activist disposition that Whites can adopt to increase their racial awareness and to support needed changes to social institutions.

\section{Research Design}

Faculty members in eight academic disciplines were interviewed as part of two studies that examined gender retrenchment and the dynamics of knowledge production in Canadian universities. While Acker's study focused on tenured academics, Muzzin's study concentrated on contingent faculty. A total of 337 faculty were interviewed. In most departments, an interview with a past or present administrator was conducted in order to further elucidate the departmental power relations.

Individual interviews were conducted in each province on 24 university campuses (representing over 25\% of higher education institutions in Canada). Where the numbers of departments in the discipline were small, we targeted all schools. We were able to visit all nine pharmacy schools, both optometry

schools, and eight of the 10 dental schools. Among the larger fields, convenience 
sampling was used to visit 11 of 21 law schools and 12 of 38 university-based nursing schools. Interviews were also conducted in academic fields with a social orientation such as education, social work and sociology. Forty-two of the interview participants (12\%) across the fields were racially minoritized and their experiences are the focus of this paper. Table 1 shows the participants' racial origins. ${ }^{6}$

Table 1

Distribution of Racially Minoritized Participants

\begin{tabular}{lc}
\hline \multicolumn{1}{c}{ Racial Identification } & Number \\
\hline East Asian & 12 \\
South Asian & 8 \\
Aboriginal & 7 \\
Middle Eastern & 5 \\
Black Canadian & 3 \\
African & 3 \\
South American & 1 \\
Caribbean & 1 \\
Mixed Heritage & 2 \\
Total & 42 \\
\hline
\end{tabular}

Following institutional ethics approval, the face-to-face interviews were audio-recorded by research team members who were experienced in qualitative research methodologies. The interview, which lasted between 90 and 180 minutes, covered a script that included semi-structured, open-ended questions about career paths, hiring and promotion experiences, individual and institutional support, mentoring and visibility. The interviews were transcribed and rendered anonymous.

The 42 transcripts were explored for emergent themes. Using discussions, this iterative approach to data collection, analysis and consultation with the research literature increased the 'density' of the themes and ensured that constructs driving the analysis reflected the data (Strauss \& Corbin, 1998). A coding structure emerged from examining, applying, refining and confirming these themes. Typical of qualitative research methodologies, there were no pre-set numbers of observations required to display rigour or significance. Rather, a given type of instance (e.g., colleague support) had to be observed repeatedly within a transcript and across the data set in order for its existence to be accepted. These common instances were clustered into themes and subthemes and interpreted through an anti-racist framework. The excerpts chosen for inclusion in this paper tended to be the most compelling examples of the themes and subthemes we identified and they represent the voices of 21 of the participants. 


\section{RESULTS}

\section{Strategies for Dealing with Isolation}

The racially minoritized academics we interviewed were either the only non-White academic or one of two to three racially minoritized faculty members in their academic units. While no interviewed institution was racially diverse, science-based academic units in larger urban centers tended to exhibit greater diversity than other fields and locations. The following three participant statements were typical: "For a long time, I was the racial minority here [in this Faculty]" (A38); "We are the only two non-White people on the faculty" (A16); and "No, no, it's a very White faculty" (A30).

Isolation was apparent in departments with limited racial diversity. The "presence" of racially minoritized faculty via what many view as "token hires" can lead to departmental complacency. Like past studies (Bronstein, 1993; Kulis \& Miller, 1988; Turner et al., 1999), the participants in our study reported that being "the one" leads to isolation, work overload, and marginality.

The under-representation of racially minoritized academics that we encountered in Canadian universities is consistent with earlier studies in North American universities. This under-representation has been attributed to a number of conditions including (1) inadequate primary and secondary education and resources; (2) low expectations of teachers and school counselors; (3) inadequate family support; and (4) insufficient mentor experiences (Battiste, 1998; Battiste et al., 2002; Marker, 1998; Moore et al., 2003; Paterson \& HartWasekeesikaw, 1994; Steinhauer, 1998).

Racially minoritized academics in the study spoke of the superior performance required of them to prove their right to be there as most were aware of the potential backlash against actual or perceived affirmative action or employment equity hires. For example, participant A16 said,

I feel I should do well - extremely well, so that nobody will say..., "It's because of her colour she is sitting there." I really don't want that to happen, so I work very hard. I always have that drive to feel that I have to do much better, or as good or much better than others, to be seen as worthy of the position that I am in and to be seen as contributing equally as the others.

The belief that superior performance translates into an average reputation and that success is scrutinized along racialized lines is supported by studies of job authority determinants (Wilson, 1997) and racially minoritized faculty reports (e.g., Johnsrud \& Sadao, 1998; Moore et al, 2003; Turner, 2003).

A few racialized academics saw any perceived marginalization as a product of some other difference. For example, participant A34 said, 
I never thought my ethnicity had anything to do with [being marginalized]. I don't know if it's my way of dealing with things and I never want to bring that up but I didn't get the feeling-that had anything to do with it.

This racially minoritized faculty member, who feels under-valued in her department, attributes her isolation to gender. Her analysis suggests three possibilities: (1) that racialization is not a causal factor in her marginalization in the academy; (2) that her well-being requires her not to acknowledge racial oppression; or (3) that her experiences in the Canadian academy have not been as overtly racist as in other environments. We saw examples of each of these interpretations. One Caribbean part-time academic (A24) had not expended energy in determining her ethno-racial location within the faculty: "I never really thought of it. Let me see. Hhm. I am [the only person of colour]-come to think of it." This Black woman said she had not reflected on her status in a professional school of about 50 academics where she was one of only two racially minoritized faculty. While she had both a Master and a $\mathrm{PhD}$ degree, the other 25 part-time faculty generally had no post-graduate degrees and a few tenured full-time faculty had not earned PhDs. Though an inequity was apparent, she saw her career as guided strictly by personal choice. Her acceptance of her career hinged on not contemplating that racialization played a role in it. Other participants, aware that their racial difference was an issue in the academy, noted colleagues who choose to ignore its impact. One racially minoritized academic (A26) referred to a colleague as "an Anglophile," believing that he had shed his cultural roots and adopted the ways of his "colonizers." Another way of managing the racialization academics experienced was to contextualize their experiences in Canada relative to earlier ones. For example, participant A34 said,

I never take any affront to [discrimination in Canada] because I kind of feel that it is not only a dilemma here. It may [just] be subtle. We may want to deny it but I've come from [Guyana], where it was very obvious. I knew no matter what education I had, I would never get up the totem pole [sic]. Here, on the other hand, I felt maybe there might be subtle things but [the racism] was not such an intrusion and did not have such a repercussion in my life so, for me.... I don't see it as a big issue. Other people may take more of an affront - [but] because of the extreme [racism] we faced as children, and as a young adult - I use it as a comparison.

This academic demonstrated two strategies for coping in the Canadian academy. While she acknowledged she was racially minoritized, her earlier personal experiences of very overt forms of racism in Guyana made her minimize the impact of discrimination she experienced in Canada. In addition, she consciously chose cultural integration in Canada: "I have deliberately taken a path of integration." 
Numerous participants spoke of daily experiences of racial insensitivity and intolerance. One woman (A25) noted that her White colleagues routinely confused her with another colleague of colour.

There was someone else [at work] whose name was [X] and we looked nothing alike but - she was about this tall [gestures] and she was, like, tiny, little, petite - her hair was short. Really we looked nothing alike but people were constantly mixing U.S. up. Constantly! So I would just reply by mixing them up. So just - just these subtle little things that you have to work with.

This faculty member chose to confront her White colleagues by pretending to confuse them though one might speculate that her "playfulness" was probably lost on her colleagues. Pointing out racially insensitive behaviour, even if it is unintended, is a risky, stressful and tiring activity especially when "these subtle little things" form a pattern of exclusion in the workplace. Another participant (A39) remembered one of her White colleagues saying, "I didn't realize these Chinese students are so nice-looking when they're all dressed up." She went on to comment on hurtful types of remarks made by some colleagues: "What's scary is I don't think sometimes some of [my colleagues] realize what they're saying or the impact of it." This academic wondered how her White colleagues felt about her: "I'm sure there are [biases] towards me - it's what I've felt many times."

Most racially minoritized faculty in this study acknowledged they were situated in White-dominated faculties and affected by their visible difference. In fact, only four of the racially minoritized academics we interviewed believed that racialization played no role in their working lives. To further elucidate the impact of this racialization, faculty perceptions regarding acceptance, mentoring, support and visibility were examined.

\section{Acceptance}

One indicator of racial equity in academia is the level of acceptance that individuals experienced regarding recruitment, hires, assignments, promotion and social fit. Although we focused our attention on the working lives of racially minoritized academics, it should be noted that the most compelling cited examples of exclusion occurred during their time as students or professionals outside of academia. Comments suggestive of these types of negative experiences include three referring to university life: "I never faced so much racism in my life, as I did at [University X]" (A38); "[It was] obvious that [I was] going to have to set aside my Aboriginal culture and beliefs in order to get through this [program] and get my degree and that's basically what I did" (A35); and "On the social level, [University Y] was incredibly alienating - it was so obviously a place of privilege" (A25).

About half of the 42 racially minoritized faculty we interviewed held contingent positions and the majority of those in tenure-track positions had 
taken longer to secure such positions than their White counterparts. These patterns $^{7}$ of contingent work among racially minoritized academics are consistent with observations of the Canadian academy (CAUT, 2004; Rajogopal, 2002). Of those who had obtained tenure, about half of the participants had experienced delays of several years. While a few of the racially minoritized faculty reported unfettered access to the academy, most had perceived some level of exclusion during their hiring, tenure and promotion processes and, in the case of contingent placements, the renewal process. The experience of multiple applications and repeated rejections for a tenure-track position left one racially minoritized contingent academic (A32) completely demoralized. Her comments included, "I feel like a loser. I totally feel like a failure ... This process is so ego-crushing .... It's going to kill me. I'm already discouraged so now I'm going to end up saying, 'Okay, I'm discriminated [against]." At a point when the hiring process had caused her to question her worth as an academic, this woman suspected that racism played a role but did not want to assume it was the cause of her exclusion from secure academic jobs. The lack of acceptance this academic felt in the hiring process is reflected in her comments about one of the interview teams she faced: "Ten old men! I mean put just one woman there, for God's sake!" This comment points to a lack of connection between the racially minoritized female candidate and the all-White male hiring committee. There was little shared space. Although she had not yet secured a job offer in North America, she had received job offers from her homeland in the Middle East. Of this, she said, "I mean I would love to be there and the more I know about this [North American] culture and this whole process, I'm missing home." Her developing sense of being in the North American academy was, "I don't belong here."

Those who had remained in contingent positions for years despite efforts to secure a tenure-track position felt excluded. As one participant (A37) stated, "Regular [sessional] is not the term I usually use. It's 'eternal sessional' because I don't think they're going to give me a job." Another racially minoritized academic (A29) echoed his sense of disconnection:

There is more to "Why are people being hired on contract positions?" than - "It's an economic...decision, or people want to be in contract positions." It's much deeper than that and it goes to...race. It goes to ability and I'm talking about physical and/or mental ability . . . It goes to sexual orientation. . . Why are those standards going up. . . ? Well they're going up because women started to break through, then racialized people started to break through. Back in the good old days if you were White and male and had a [professional degree], you could teach in a [professional] school and become tenured - end of story. Women came in and - then they escalated [the requirement] to a Masters . . . Now racialized people - they're actually escalating to $\mathrm{PhDs}$.

Some negative experiences left racially minoritized faculty suspecting, yet unable to prove they had been racially marginalized, leading to remarks like 
the one made by participant A12 who had co-written an unsuccessful grant application with another racially minoritized academic: "I felt it was very, very unfair. I don't know . . . I mean on my own judgment - probably they just noticed our two Chinese names there. I don't know. It's hard to say."

There appeared to be an assumed desire or need to integrate into the dominant culture. Everyone was welcome as long as they accepted the tacit rules in play. One racially minoritized faculty member (A27) was asked during the interview about a large promotional banner on the outside of the faculty building showing a racially mixed and gender balanced group of students:

It's a source of unbelievable cynicism within the faculty - like - oh come on! To tell you the truth, it's actually not at all representative.... There were two White males out of a group of nine [shown on the poster] and that's not representative actually but it's got "the balance."

This academic was savvy to the institution's wish to suggest racialization and gender are non-issues. Despite a notable rise in student enrolment over the years of women and Asians, considerably more than half of the men were White. The idea that academia is "colour-blind" was rejected by most racially minoritized participants.

There were few indications that racially minoritized faculty socialized with their colleagues. Heavy workloads and family responsibilities were obvious contributing factors but some spoke of social alienation and isolation within their own faculty. One Aboriginal woman (A17) spoke of how she experienced the lack of social interaction within her academic department:

They don't talk to me. ... I don't go chumming around with anyone. I don't go to coffee. I mean, nobody does that. . . . For me, it is not a very social department. What they perceive to be equal may be equal from their perspective but it's not my equality.

Another racially minoritized academic (A26) saw the lack of voice in institutional policy experienced by contingent workers as an important factor in creating barriers to potential connections with colleagues,

I think that being a sessional, a part-time person, here, in certain ways - because of that isolation - deprives you as much as the issue of being deprived of participation in the policy. ... I would hazard a guess that it also deprives you of whatever kind of solidarities that you could have and [the] kinds of personal intersections that you might have with people.

This pattern of delayed or obstructed careers and social disconnection brings into relief a system that, through non-acceptance, excludes rather than includes racially minoritized academics. 


\section{Mentoring}

Most of the racially minoritized faculty members had experiences of being a mentor but not in being mentored. Only one participant identified the department head as a mentor. The comments from two of the academics were typical: "So I've been pretty much on my own. On the other hand, I'm there for the students" (A17); and "Me being mentored by someone else? Not at [University X].... Yes [I mentor students]" (A24). Racially minoritized faculty felt their scarce representation obligated them to mentor and act as a role model to racially minoritized students. As one tenured Aboriginal faculty member (A19) said,

I was the first member of the [specific Aboriginal band] to get a Master's degree in any discipline and at the time, I think there [were]...four or five [Aboriginal academics] in Canada so I felt...an interest and also a certain degree of responsibility to role model.

Some racially minoritized contingent academics found that the impermanence of their positions lessened their chances to be mentored. As one academic (A40) noted,

I don't think that anyone went out of their way to mentor me. . . but on the other hand, I don't think that I actively sought out people who might be mentors for me, you know. And the whole thing has to be placed in the context of the impermanence of my condition at that time.

After being hired, participant A34 attempted to find a mentor, "So I phoned up [the teaching support department] and I said, 'I'm looking for a mentor.' (laughs) It goes to show how naive I was!" Few academic institutions adopt formal professional enhancement models that ensure academic hires are mentored (Lowe et al, 1991) so academics must find their own mentors. The challenge for women and racially minoritized academics is that they struggle to find a mentor among established faculty who are typically White men who tend to associate more with protégés similar in gender, race and social class (Noe, 1988; Wright \& Wright, 1987).

Participant A30 noted that he waited until his fourth university degree to encounter a mentor although he routinely mentored racially minoritized students. Of his mentor during his $\mathrm{PhD}$ program, he said, "I finally got a mentor - a 'worth [the] wait' mentor." He saw a worthy mentor, not as someone with whom he could racially identify but as someone who could facilitate his connection to the people with power in his profession. The reality was that it would have been hard to find a racially minoritized mentor that was as "connected" as his White mentor.

For those representing the intersection of multiple differences, their mere presence served as a role model. One Aboriginal woman on faculty (A38), who publicly identifies herself as lesbian, said, 
I think I'm a role model by [the] virtue of just being here and being out and being proud of ... being an Aboriginal. .. Just by being there, in front of a class... I make a statement and I think, by extension, this. .. School makes a statement.

We found the participants' mentoring experiences were consistent with U.S. studies that show faculty of colour are less likely to have a mentor (Turner et al., 1999) but more likely, through their service assignments, to be a mentor (Garza, 1993; Smith \& Witt, 1993; Staples, 1984; Wiley, 1992). However, activities that involve increased student contact time directly translate into lower research productivity (Konrad, 1991). While racially minoritized faculty mentor students at the expense of their research, "superstar research positions" (Krouse, 1999, p. 220), with lower teaching loads, less student contact, and greater freedom regarding service responsibilities, are more typically offered to White men, providing the university with the academic prestige associated with prolific traditional research. ${ }^{8}$

The applicability of the traditional patriarchal mentor-protégé role to women and racially minoritized academics has been questioned (Chandler, 1996; Paterson \& Hart-Wasekeesikaw, 1994). Alternative nonhierarchical, holistic mentoring and support networks have been proposed in which the mentor fosters "a learner-directed approach that acknowledges the power of experience, narrative, and intuition in learning" (Paterson \& HartWasekeesikaw; 1994, p. 75).

\section{Support}

Despite few mentors, most racially minoritized faculty had experienced some collegial support. Participants pointed to remuneration, hiring, tenure and promotion decisions, resource support or daily instances as indicators of support. Participant A32 acknowledged collegial support: "So when I came here, I started to learn about [the] Canadian job market through these guys [sic] and they've been really supportive. . . I mean they showed some interest at least." Another participant (A5) contrasted obtaining support but not mentors: "There are quite a few people that are good - that have been very supportive but if you're talking about one mentor or two that take you through and guide you - No."

Most contingent participants applied for tenure-stream positions within their departments. Those who were successful on the first attempt reported being pleased with their support. Participant A27 said, "I got very good support from the faculty and from the Dean. So they've been very supportive and very interested and helpful." Interestingly, this participant did not reflect on having completed one undergraduate degree and four graduate degrees before securing a tenure-track position. Applying within a department where one is a "known entity" posed some challenges for racially minoritized academics. Participant A40 commented, 
I noticed that I received more support from some members of faculty than others. I mean you cannot avoid noticing that.... But if I was not here, I would not be subject to that kind of divided support from faculty. ... Nobody would have made up their minds - would have been able to make up their minds about me - not necessarily based on what is on my documents. . . but based on inter-personal relationships.

This contingent academic repeatedly applied for a tenure-track position over a four-year period before attaining the position. Although he acknowledged some advantage in understanding the inner workings of the department, he noted a response to him that felt too personal and political.

Administrative support, at the level of the dean or department head, was mixed. For example, after four years in a contingent position, A40 received an unsolicited letter from his dean, congratulating him on his teaching ability. He was able to include this letter with his successful application for a tenuretrack position in a department where teaching was highly valued. Another participant (A36) praised the support she received:

I have to say [Dean $\mathrm{Z}$ was supportive] especially with my position [as Equity Officer] - she actually suggested [a larger budget] - and she recognized the work I was doing and that made me feel good and supported - and. . [ [that] always gives one encouragement to carry on.

In contrast, promotion and tenure experiences made numerous participants not trust their administrators. Sudden support from a notoriously unsupportive dean led one academic (A34) to say, "I was very suspicious of him and still am." After participant A26 discovered the dean had lied about supporting her during her failed tenure application, she told him in a meeting that, "I thought he was an 'abject liar'. I mean those were my words." We found the most compelling examples of feeling unsupported by and excluded from the academy pertained to promotion and tenure experiences. While the academy let racially minoritized academics in through the contingency door, full acceptance into tenured positions appeared to be a more elusive goal. By largely restricting equity hires to the contingency category, universities can still argue they are committed to employment equity ${ }^{9}$ without substantially or permanently changing the make-up of the university.

Remuneration, benefits and resource support (e.g., library privileges, computers) generally fell along job lines. Contingent faculty were less likely than tenure-stream faculty to receive professional development support, sabbaticals or benefits, which when present were usually prorated unless the individual held a 100\% position. The lower infrastructural support experienced by contingent academics has been reported (Gappa \& Leslie, 1993; Muzzin, 2003). Although these challenges are not unique to racially minoritized faculty, the channeling of this cohort into contingent work means that overall, less infrastructural 
support exists for them. Racially minoritized contingent academics spoke about their inadequate remuneration. Participant A38 said, "I'm the person with the longest title and shortest pay cheque" while another (A31) commented,

[The job] is hampered by a couple of things. One is low-level salary. .. not competitive to markets for [my profession]. . . Back in. . . about 1990 , I was being paid about $\$ 37,000 \ldots .$. It never increased [in five years]. ... [But a] wonderful working environment. Good supportive colleagues and good supportive departments. ... They were wonderful - a President who truly believed that we should be doing this -that [equity] was part of the mandate of the University.

This woman struggled with the contradiction between the support for her work and the externally-funded low salary. Interestingly, the woman perceived the university as entirely supportive even though it never bridged the salary gap of her soft money position. As indicated in other studies, the reliance on "soft" funding for certain university programs highlights what types of knowledges the university does not actually support (Johnsrud \& Sadao, 1998; Turner, 2003).

\section{Visibility}

Racially minoritized faculty we interviewed cited instances where they had made a difference. Participant A40, in his capacity as equity assessor on a departmental hiring committee, found a racialized applicant within the department was unfairly characterized: "I succeeded in reversing the decision on that occasion. So I think equity assessors can be effective if they want to be."

Racially minoritized contingent academics, who held full-time or substantial part-time positions, found they had a voice on at least some issues through their many committee assignments. Sometimes, committee work became too onerous and compromised other productivity. In his first year as a contingent academic, participant A40 was expected to sit on five committees, teach a full course load and develop a research program. The norm was to be "the only person of colour on a committee."

A "don't rock the boat" strategy was common among the racialized faculty, even for those trying to effect change in their departments and professions. A tenured racially minoritized faculty member (A18) approaching retirement said,

Even if I think I know racism or sexism is playing a part, I'll never say it openly. I'll bring up other things to say how wonderful [a candidate is]. . . because I don't want to alienate the people [with] whom I have to work. ... The silent majority exercises its power very effectively. They have to work so little to keep things going the way they are. Those of U.S. who want to change it, have to work so much harder. 
This participant's strategy reflects Turner's (2003) description of working towards change from the margins of power. When A40 held a contingent position, he felt it would be politically unwise to object when his department offered a less qualified, White external candidate the tenure-track position instead of him:

No, I didn't. I didn't tell anybody. They know. In these issues, discretion may be the better part of valour. . . because I was still looking forward to future competition. I did not think that it was tactically wise to come up strong about my observations of the recruitment process.

Careful decisions had to be made regarding when and how to raise issues of intolerance or bias. For those who wished to act as social change agents, the acquisition of tenure provided them with the security to proceed. This same academic - now recently tenured - went on to comment:

I intend to focus very intensely on social justice issues. . . unless people like U.S. take it up, who are we going to expect to take the issues up? There are so many of those issues in Canada. . . in our immediate environment, and within the context of the. . . world -and [I] need a platform from where to begin to put my views out. . . thank goodness I've found one in the faculty here.

Participant A36, an equity officer, maintained hope despite feeling unheard within the university,

When people come to me - some of my Aboriginal colleagues - and they say, "Things are really bad on this campus. They're not listening to U.S.. They're not paying attention." - and some of that is absolutely true - I always think, well - but if we don't have hope and if we look back at our mothers' generations, things have progressed and things have come a long way.

Racially minoritized academics face conflicting challenges. Many want to increase their visibility within the academy, in part, as change agents but these efforts may occur at the expense of research time, career advancement and personal well-being. The academy's need to keep racially minoritized faculty seen but not heard unless they follow institutionally sanctioned topics and tacit assimilationist strategies, places a tremendous burden on these academics.

\section{Discussion}

Interviews of 42 racially minoritized academics in Canadian universities revealed perceptions consistent with constructs of an anti-racist framework. These academics reported that their racial identities affected their social locations and their voices in academic units where the institutional "norm" was 
androcentric, White and Eurocentric. Coping strategies for navigating these different spaces included over-performing in order to compete with their White colleagues, minimizing racially-based aspects of their negative experiences, and less often because of the risks involved, confronting their colleagues and superiors about racially intolerant or insensitive behaviour.

Although the racially minoritized faculty we interviewed appeared as well qualified as their White colleagues, they felt they were less likely to be hired, tenured and promoted along the same time-lines as their White counterparts. This led to experiences of exclusion and disconnection within the academy. Racially minoritized faculty tended to be mentors but not have mentors. Those with mentors rarely found one who was also racially minoritized; thus, it can be argued that their mentors would not typically be in a position to understand their sense of cultural disconnection from the academy.

While most racially minoritized faculty reported that they enjoyed some level of collegial support, administrative support was mixed. The most telling experience regarding support occurred around promotion and tenure decisions, suggesting racially minoritized faculty were welcome in the Canadian academy as long as they did not seek places with greater power, prestige, and permanence.

By necessity, racially minoritized academics often chose a "don't rock the boat" approach, even when seeking to act as social change agents. There was risk in suggesting ways of thinking or behaving that were different from the White, Eurocentric, androcentric model. Racially minoritized academics struggled with their visibility in that they were frequently invited to participate on committees as a "representative" of a marginalized group but the time commitment and lack of recognition often became problematic. Thus it can be argued that their visibility likely serves the institution's purposes rather than the overall goal of real equity in the academy.

Our observations resonate with three key anti-racist framework perspectives - that racialization is a fundamental organizing principle in Canadian society, that racialization is the "norm" in the Canadian academy, and that experiences of oppression give racially minoritized academics a unique voice that needs to be heard. Our data also reveal the complexities generated by the intersection of multiple identities in that the experiences of racially minoritized individuals may be heightened or transformed by the co-existence of other identities. As a result, some participants attributed their experiences of inclusion, or lack thereof, in the Canadian academy to a particular identity (e.g., race), while others attributed their experiences to the intersection of multiple identities (e.g., race and gender). The fact that the relative contributions of multiple identities cannot be quantified or teased apart by either the participants or observers does not diminish the veracity of the findings. Some might argue that at least some participants' comments merely reflect a "personal take" on or a "personal reaction" to a given situation and as such do not constitute proof of racially-based hegemony. Such a perspective attempts to "individualize" a specific experience without acknowledging that each of U.S. "experience" 
events through a lens focused by prior and repeated experiences. Of importance to U.S. is the fact that these racially minoritized academics routinely interpret their experiences of exclusion in the Canadian academy as at least partially racially located.

These findings suggest that significant institutional reforms are needed in Canada before racially minoritized faculty members feel accepted, visible, and supported in their working lives. This bleak characterization of the Canadian academy can be partially offset with a growing literature that helps U.S. envision the paradigm shifts that are necessary to achieve a more substantive equity. Achieving such equity requires educational reforms at all levels (elementary through university) that espouse the values of antiracism, multiculturism, and inter-racial communities (Blum, 1991) and enable members within the academic community to develop cross-cultural competence (Laroche, 2003). The academy's current definition of success needs to broaden from one that values independent acts (e.g., grant writing, publishing) and privileged knowledge (i.e., androcentric, White, Eurocentric knowledge) to one that includes the collaborative infrastructure of the academic community (e.g., mentoring, curriculum development) and knowledges that are currently subjugated (Collins, 1998; Ely \& Meyerson, 2000; Graveline, 1998). Within this value system, alternative mentoring programs should be implemented - such as mosaic mentoring where multiple advisors and experiences are available to address a diversity of newcomers and their evolving needs (e.g., NFIE, 1999).

We should also note that despite the negative experiences that many of our participants shared with U.S., almost all spoke of positive aspects of their job and a passion for their work. Even participant A26, who had recounted numerous overtly racist experiences during her career, said this of her institution:

You can form a picture of an institution by just passing on these experiences that [are] quite negative and actually quite legitimately felt. In my case, it would be a distortion of the institution to just highlight those particular experiences and say that they were determinative of my current experience. [Rather] they give insight into where people [have been].

The mission statements of Canadian universities have always espoused teaching and research excellence and more recently added concepts such as equity, diversity, freedom and mutual respect. The next step is to create an understanding of what teaching and research excellence looks like in an inclusive and equitable environment where all members thrive and work towards this state. 


\section{NOTES}

${ }^{1}$ SSHRC grants: 1999 (PI: L. Muzzin; Investigators: M. Boyd, F. Gregor, \& M. Spafford; Collaborators: C. Albas, A. Mysyk, V. Nygaard, \& M. Wallis); 1995 (PI: S. Acker; Investigators: L. Muzzin, M. Boyd, C. Baines, \& G. Feuerverger).

${ }^{2}$ The 42 racially minoritized academics considered in this paper were an assigned anonymous number between A1 and A42.

${ }^{3}$ We have described these disciplines as historically 'White' based on an analysis of Canada's immigration policies in the $20^{\text {th }}$ century and census data since 1981. In the first half of the $20^{\text {th }}$ century, Canadian immigration policies selectively targeted British and American immigrants, followed by northern and then central Europeans; Asians, Blacks and Jews were considered the least desirable (Virtual Museum of Canada, 2002). Canada began to liberalize its immigration policies in 1948 and to employ a points system in 1967. Canada's population continues to be predominantly (86.8\%) 'White' (Bélanger \& Malenfant, 2005), although the proportion of racially visible minority groups has begun to grow in recent years: $5.0 \%$ in $1981,13.2 \%$ in 2001 , and $19.1 \%$ projected in 2017 (Bélanger \& Malenfant, 2005; Tran, 2004). We have capitalized 'White' and 'Black' to acknowledge these are political terms.

${ }^{4}$ We acknowledge the difficulties in establishing a classification system that accurately and fairly describes an individual's ethno-racial identity and we appreciate the problems created by grouping together an ethno-racially diverse collection of individuals. While the terms racial minority or visible minority might describe those individuals whose ethno-racial identification specify a numerical under-representation in society, we have chosen the term "racially minoritized" to denote those individuals whose ethno-racial identification means that they are under-represented both in number and social capital in a Caucasian-dominated Canadian society.

${ }^{5}$ Determining the academic contingent workforce size is difficult because reporting is voluntary and the definition of contingent varies. What can be said is that the proportion of academic contingent workers is growing in North America.

${ }^{6}$ Most racially minoritized participants self-identified their racial origin(s) during the interview. There were a few faculty of colour who restricted their identification to being born outside Canada. As their experiences were similar to those who specifically self-identified their racial origin, their interviews remained part of the data set.

${ }^{7}$ The proportion of contingent workers in our study ( 50\%) should be considered in terms of our sampling strategy. Thus, the patterns rather than the exact proportions of racially minoritized faculty in different career paths should be noted. 
${ }^{8}$ Canadian Research Chairs are more often White and overwhelmingly male (http://www.chairs.gc.ca/web/home_e.asp).

${ }^{9}$ Institutions are required to make a commitment to: women, visible minorities, Aboriginals, and persons with disabilities.

\section{ACKNOWLEDGEMENTS}

We are indebted to the participants, SSHRC, as well as Begna Dugassa, Kimine Mayuzumi, Linda Muzzin and Riyad Shahjahan, who contributed valuable comments in the analysis and the paper.

\section{REFERENCES}

Alcoff, L. (1988). Cultural feminism versus post-structuralism: The identity crisis in feminist theory. Signs, 13(3), 405-436.

Allen, W. R., Epps, E. G., Guillory, E. A., Suh, S. A., \& Bonous-Hammarth, M. (2000). The Black academic: Faculty status among African Americans in U.S. higher education. Journal of Negro Education, 69(1-2), 112-127.

Astin, A. W. (1982). Minorities in American higher education: Recent trends, current prospects, and recommendations. San Francisco: Jossey-Bass.

Astin, H. S., Antonio, A. L., Cress, C. M., \& Astin, A. W. (1997). Race and ethnicity in the American professoriate, 1995-96. Los Angeles: Higher Education Research Institute, Graduate School of Education \& Information Studies.

Battiste, M. (1998). Enabling the autumn seed: Toward a decolonized approach to Aboriginal knowledge, language, and education. Canadian Journal of Native Education, 22(1), 16-27.

Battiste, M., Bell, L, \& Findlay, L. M. (2002). Decolonizing education in Canadian universities: An interdisciplinary, international, indigenous research project. Canadian Journal of Native Education, 26(2), 82-95.

Bélanger, A., \& Malenfant, É.C. (2005). Population projections of visible minority groups: Canada, provinces and regions, 2001 - 2017. Statistics Canada, Catalogue \#91-541-XIE. Accessed on July 15, 2005 at http://www.statcan.ca.

Benjamin, L. (1997). Black women in the academy: Promises and perils. Gainesville: University Press of Florida.

Benoit, C. M. (2002). Women, work and social rights: Canada in historical and comparative perspective. Toronto: Prentice Hall/Allyn and Bacon.

Blackwell, J. E. (1989). Mentoring: An action strategy for increasing minority faculty. Academe, 75(5), 8-14. 
Blum, L. A. (1991). Antiracism, multiculturalism, and interracial community: Three educational values for a multicultural society. University of Massachusetts Distinguished Lecture Series, 1991-1992. Office of Graduate Studies and Research, University of Massachusetts at Boston.

Boice, R. (1993). Early turning points in professional careers of women and minorities. New Directions for Teaching and Learning, 1993(53), 71-79.

Bronstein, P. (1993). Challenges, rewards, and costs for feminist and ethnic minority scholars. New Directions for Teaching and Learning, 1993(53), 61-70.

Calhoun, G., Ross, J. L., \& Bolton, J. A. (1990). Black professors in higher education: A vanishing breed? The College Student Journal, 23(4), 323-331.

Calliste, A. (2000). Anti-racist organizing and resistance in academia. In: A.M. Calliste \& G.J.S. Dei (Eds.), Power, knowledge and anti-racism education: A critical reader (p. 141-161). Halifax: Fernwood Publishing.

CAUT. (2004). Closing the equity gap: A portrait of Canada's university teachers, 1996-2001. CAUT Education Review, 6(2), 1-5.

Chandler, C. (1996). Mentoring and women in academia: Reevaluating the traditional model. National Women's Studies Association Journal, 8(3), 79-100.

Collins, P. H. (1998). Fighting words: Black women and the search for justice. Minneapolis: University of Minnesota Press.

D’Andrea, M., \& Daniels, J. (1999). Exploring the psychology of White racism through naturalisitic inquiry. Journal of Counseling and Development, 77(1), 93-101.

Darden, J. T., Kamel, S. M., \& Jacobs, A. J. (1998). Black faculty in predominantly White U.S. institutions of higher education: The influence of Black student enrollment. Equity \& Excellence in Education, 31(2), 6-18.

Dei, G. J. S. (1996). Theory and practice: Anti-racism education. Halifax: Fernwood Publishing.

Delgado, R., \& Stefancic, J. (2001). Critical race theory: An introduction. New York: New York University Press.

Dhruvarajan, V. (1996). The chilly climate in BC universities. In: D. Hearne \& M. L. Lefebvre (Eds.), Equity and justice. Montreal: Canadian Women's Studies Association.

Dreher, G. F., \& Ash, R. A. (1990). A comparative study of mentoring among men and women in managerial, professional, and technical positions. Journal of Applied Psychology, 75(5), 539-546.

Dua, E., \& Robertson, A. (1999). Scratching the surface: Canadian, antiracist, feminist thought. Toronto: Women's Press. 
Ely, R. J., \& Meyerson, D. E. (2000). Theories of gender in organizations: A new approach to organizational analysis and change. In: B. Staw \& R. Sutton (Eds.), Research in organizational behavior, Vol. 22 (p. 105-153). Kidlington, Oxford: Elsevier Science \& Technology.

Essien, V. (2003). Visible and invisible barriers to the incorporation of faculty of color in predominantly white law schools. Journal of Black Studies, 34(1), 63-71.

Evans, J. (2004). Men nurses: A historical and feminist perspective. Journal of Advanced Nursing, 47(3), 321-328.

Flowers, L. A., \& Jones, L. (2003). Exploring the status of Black faculty utilizing data from the National Study of Postsecondary Faculty. The Journal of Men's Studies, 12(1), 3-13.

Gappa, J. \& Leslie D. (1993). The invisible faculty. Improving the status of part-timers in higher education. San Francisco: Jossey-Bass.

Garza, H. (1993). Second-class academics: Chicano/Latino faculty in U.S. universities. New Directions for Teaching and Learning, 53(Spring), 33-41.

Graveline, F. J. (2000). Lived experiences of an Aboriginal feminist transforming the curriculum. In C. James (Ed.), Experiencing difference (p. 283293). Halifax, NS: Fernwood Publishing.

Graveline, F. J. (1998). Circle works: Transforming Eurocentric consciousness. Halifax: Fernwood Publishing.

Hannah, E., Paul, L., \& Vethamany-Globus, S. (2002). Women in the Canadian academic tundra: Challenging the chill. McGill-Queen's University Press.

James, C. E. \& Shadd, A. (2001). Talking about identity: Encounters in race, ethnicity and language. Toronto: Between the Lines Press.

Johnsrud, L. K., \& Sadao, K. (1998). The common experiences of "otherness": Ethnic and racial minority faculty. The Review of Higher Education, 21(4), 315342.

Knowles, M. F., \& Harleston, B. W. (1997). Achieving diversity in the professoriate: Challenges and opportunities. Washington, DC: American Council on Education.

Konrad, A. (1991). Faculty productivity and demographics. Thought and Action: The NEA Higher Education Journal, 7(2), 19-54.

Krouse, M. B. (1999). Women and the university as corporation: A call for feminist response. In S. Brodribb (Ed.), Reclaiming the future: Women's strategies for the $21^{\text {st }}$ century (p. 215-234). Charlottetown, PEI: Gynergy Books.

Kulis, S., \& Miller, K. A. (1988). Are minority women sociologists in double jeopardy? The American Sociologist, 19(4), 323-339. 
Laroche, L. (2003). Managing cultural diversity in technical professions. Butterworth/Heinemann, Boston.

Leap, T. L. (1995). Tenure, discrimination, and African-American faculty. The Journal of Blacks in Higher Education, 7(Spring), 103-105.

Levinson, W., \& Weiner, J. (1991). Promotion and tenure of women and minorities on medical school faculties. Annals of Internal Medicine, 114(1), 63-68.

Lewis, S. (1992). Report to the Premier on racism in Ontario. Ontario: Office of the Premier.

Lowe, A. A., Boyd, M. A., \& Brunette, D. M. (1991). Mentoring and pretunure faculty development. Journal of Dental Education, 55(10), 675-678.

Luther, R., Whitmore, E., \& Moreau, B. M. (2003). Seen but not heard: Aboriginal women and women of colour in the academy. Ottawa: Canadian Research Institute for the Advancement of Women.

Maher, F. A., \& Tetreault, M. K. (1993). Frames of positionality: Constructing meaningful dialogues about gender and race. Anthropological Quarterly, 6667(3), 118-126.

Marker, M. (1998). Reflections from the field. Going native in the academy: Choosing the exotic over the critical. Anthropology \& Education Quarterly, 29(4), 473-480.

McDowell, T., \& Jeris, L. (2004). Talking about race using critical race theory: Recent trends in the Journal of Marital and Family Therapy. Journal of Marital and Family Therapy, 30(1), 81-94.

McLean, J. (2003). Men as minority. Men employed in statutory social care work. Journal of Social Work, 3(1), 45-68.

Menges, R. J., \& Exum, W. H. (1983). Barriers to the progress of women and minority faculty. Journal of Higher Education, 54(2), 123-144.

Moore, J. L. III, Madison-Colmore, 0., \& Smith, D. M. (2003). The ProveThem-Wrong Syndrome: Voices from unheard African-American males in engineering disciplines. The Journal of Men's Studies, 12(1), 61-73.

Morgan, J. (1993). Women leaders of colour call for coalition and unity to advance concerns. Black Issues in Higher Education, 10(2), 22-23.

Moser, R. (2000). The AAUP organizes part-time faculty. Bulletin of the American Association of University Professors, 86(6), 34-37.

Mukherjee, A. (2001). The "race consciousness" of a South Asian (Canadian, of course) female academic. In: C. E. James \& A. L. Shadd (Eds.), Talking about identity: Encounters in race, ethnicity and language (p. 201-207). Toronto: Between the Lines. 
Mullens, A. (2001). The sessional dilemma. University Affairs, May, 10-13 $\& 25$.

Muzzin, L. (2003). How fares equity in an era of academic capitalism? The role of contingent faculty. Canadian Federation of the Humanities and Social Sciences International Colloquium on Transformation of Academic Culture: Capital Accumulation and International Competitiveness, Halifax, Nova Scotia.

Mysyk, A. (2001). The sessional lecturer as migrant labourer. Canadian Journal of Higher Education, 31(3), 73-92.

Nakanishi, D. T. (1993). Asian Pacific Americans in higher education: Faculty and administrative representation and tenure. New Directions for Teaching and Learning, 53(Spring), 51-59.

National Foundation for the Improvement of Education (NFIE). (1999). Creating a teacher mentoring program. Washington, DC.

Ng, R. (1994). Sexism and racism in the university. Canadian Woman Studies, 14(2), 41-46.

Noe, R. A. (1988). Women and mentoring: A review and research agenda. Academy of Management Review, 13(1), 65-78.

Nygaard, V. L. (2002). The marginalization of sessional faculty as an impetus to unionize. Paper presented at the Canadian Sociology and Anthropology Association Meetings. Toronto, Ontario.

Palepu, A., Carr, P. L., Friedman, R. H., Amos, H., Ash, A. S., \& Moskowitz, M. A. (1998). Minority faculty and academic rank in medicine. Journal of the American Medical Association, 280(9), 767-771.

Paterson, B, \& Hart-Wasekeesikaw, F. (1994). Mentoring women in higher education: Lessons from the elders. College Teaching, 42(2), 72-77.

Petersdorf, R. G., Turner, K. T., Nickens, H. W., Ready, T. (1990). Minorities in medicine: Past, present and future. Academic Medicine, 65(11), 663-670.

Rajogopal, I. (2002). Hidden academics: Contract faculty in Canadian universities. Toronto: University of Toronto Press.

Ramey, F. H. (1993). Mentoring: Its role in the advancement of women administrators in higher education. Black Issues in Higher Education, 10(17), 116.

Reid, P. T., \& Wilson, L. (1993). How do you spell graduate success? NETWORKS. Black Issues in Higher Education, 10(10), 100.

Reynolds, C. (2001). The education system. In: N. Mandell (Ed.), Feminist issues: Race, class and sexuality, $3^{\text {rd }}$ Edition (p. 242-259). Toronto: Pearson.

Riley, S., \& Wrench, D. (1985). Mentoring among women lawyers. Journal of Applied Social Psychology, 15(4), 374-386. 
Sands, R. G., Parson, A.L., \& Duane, J. (1992). Faculty-faculty mentoring and discrimination: Perceptions among Asian, Asian American, and Pacific Island faculty. Equity \& Excellence, 25(2-4), 124-129.

Scott, R. R. (1981). Black faculty productivity and interpersonal academic contacts. Journal of Negro Education, 50(3), 224-236.

Smith, E. \& Witt, S.L. (1993). A comparative study of occupational stress among African American and White university faculty: A research note. Research in Higher Education, 34(2), 229-241.

Sokoloff, N. J. (1992). Black women and white women in the professions: Occupational segregation by race and gender, 1960-1980. New York: Routledge.

Stalker, J. \& Prentice, S. (Eds). (1998). The illusion of inclusion: Women in post-secondary education. Halifax: Fernwood Publishing.

Staples, R. (1984). Racial ideology and intellectual racism: Blacks in academia. The Black Scholar, 15(2), 2-17.

Steinhauer, N. (1998). Native viewpoints: Higher education and Native students. Canadian Social Studies, 32(4), 115.

Strauss, A. L., \& Corbin, J. (1998). Basics of qualitative research: Techniques and procedures for developing grounded theory. $\left(2^{\text {nd }}\right.$ ed). Thousand Oaks: Sage Publications.

The Chilly Collective (Eds). (1995). Breaking Anonymity: The chilly climate for women faculty. Waterloo: Wilfrid Laurier University Press.

Tran, K. (2004). Visible minorities in the labour force: 20 years of change. Canadian Social Trends, 73, 7-11. Statistics Canada, Catalogue \#11-008. Accessed on July 15, 2005 at http://www.statcan.ca.

Tudiver, N. (1999). Universities for sale: Resisting corporate control over Canadian higher education. Toronto: James Lorimer \& Co.

Turner, C. S. (2003). Incorporation and marginalization in the academy: From border toward center for faculty of color? Journal of Black Studies, 34(1), 112-125.

Turner, C. S. V., Myers, S. L. Jr., \& Creswell, J. W. (1999). Exploring underrepresentation: The case of faculty of colour in the Midwest. The Journal of Higher Education, 70(1), 27-59.

Virtual Museum of Canada (2002). Open Hearts. Closed doors. The War Orphans Project. Accessed on July 15, 2005 at http://www.virtualmuseum.ca.

Wennerås, C. \& Wold, A. (1997). Nepotism and sexism in peer-review. Nature, 387(6631), 341-343.

Wild, D. J. (2000). Minorities in higher education: Seventeenth annual status report. Washington, DC: American Council on Education. 
Wiley, E. III. (1992). Ability to manage students and collegial expectations key in Black faculty success. Black Issues in Higher Education, 9(December 17), 10-11.

Wilson, G. (1997). Pathways to power: Racial differences in the determinants of job authority. Social Problems, 44(1), 38-54.

Wilson, R. (1987). Recruitment and retention of minority faculty and staff. AAHE Bulletin, Feb, 11-14.

Wright, C. A., \& Wright, S. D. (1987). The role of mentors in the career development of young professionals. Family Relations, 36(2), 204-8.

\section{CONTACT INFORMATION}

Marlee M. Spafford, OD, PhD, FAAO

Associate Professor, University of Waterloo, School of Optometry

200 University Avenue West

Waterloo, Ontario, N2L 3G1

(519) 888-4567, ex 36286

mspaffor@uwaterloo.ca 